\title{
10C Model for Cultivating Application-oriented Talents Based on Ability \\ Oriented and Cooperative Education
}

\author{
MAO Chen-lei ${ }^{1}$ \\ 'Jiangxi University of Technology, 330098 Nanchang, China \\ Humao120@qq.com
}

Keywords: Application-oriented; Cooperative Education; Curriculum system; Ability.

\begin{abstract}
Based on the opportunities and challenges in application-oriented universities, this paper analyzes the problems of cultivating application-oriented talents in Chinese universities. 10C model of cultivating application-oriented talents is constructed. The model consists of unique Concept of development, characteristic Curriculum system, Creation education, school-enterprise Cooperation, education method based on CDIO, Comprehensive ability, Competence Skills, Communication ability, capable Citizens and Cloud thinking.
\end{abstract}

\section{Opportunities and challenges}

Some "985 Project" universities and "211 Project" universities are training academic research talents. The process of training is focus on the theoretical teaching, supplemented by case studies or experiments, students are required to master the knowledge systematically and thoroughly, and can discern the tracking frontier, formed a unique professional knowledge and research ability. Higher vocational colleges are training skilled talents for occupation. Students do not need to have thorough understanding and grasp of professional knowledge, but through the master of professional knowledge and methods, can solve practical problems in production and service in a certain professional skills. Other universities are training applied talents. Students should not only have a thorough understanding and grasp of professional knowledge, but also be able to use professional knowledge to solve practical problem in production practice, and has certain innovation and creativity. The applied talents in this paper refers to this kind.

With the development of Chinese social economy and the popularization of higher education, application-oriented colleges have become an important part of higher education system, play more and more prominent role in cultivating high-quality and practice-oriented applied talents. On the basis of reality needs of economic and social development for diversified talents, development of the cultivation of applied talents is the inevitable trend of the development of higher education. However, currently many application-oriented universities are not coordinated in the scale and quality of school education development. Connotation development strategy of application-oriented colleges, is an opportunity, but also a challenge.

On the one hand, connotation development strategy pointed out the development direction for application-oriented universities. In order to cultivate talents meet the needs of economic and social development, application-oriented universities must improve their own competitiveness, change traditional extensive development mode to the way of content development, improve the quality as the core, optimize the structure, strengthen the characteristics, focus on innovation. On the other 
hand, connotative development of application-oriented universities put forward higher requirements for application-oriented universities. Colleges and universities should explore and practice in the educational orientation, professional structure and curriculum characteristics, innovation and other aspects, accelerate the pace of reform, improve teaching quality, and cultivate talents to meet the needs of national economic and social development.

\section{Current problems in cultivating application-oriented talents}

(1)Higher self-positioning. Since, although the majority of application-oriented universities improve understanding applied talents problems, however, because of a dream of changing into academic university is difficult to eliminate, there are still a lot of universities to set higher position for talent training, resulting in rising demand, big, ambitious, convergence tendency. These universities cannot find their own position in the university ecological classification system. Position of level of talent training is the premise and the foundation of talent training orientation and the construction mechanism. In fact, in addition to the "985 Project" or the "211 Project" academic universities, local colleges and universities should fully consider the most basic situation of professional construction of their discipline and academic accumulation, combined with the actual regional economic and social development of the industry. According to the reality and the future needs of the talent market, application-oriented or skills talents are cultivated.

(2)Imbalance of major structure. Essence of applied talents is in its application. However, Chinese application-oriented universities still exist problems in imbalance of major structural. First of all, many colleges and universities with the continuous expansion of enrollment and campus expansion, set new majors without sufficient market research and industry trend analysis, resulting in a lot of new majors do not meet the needs of economic and social development. Secondly, college enrollment is still in a major division, students' training is in fixed major, resulting in single major ability, which is not conducive to the formation of comprehensive ability and scientific literacy, employment ability and strain capacity is not strong. Thirdly, the impact of large enrollment since the end of the twentieth century, many universities keen on new majors, popular major construction, lack of brand consciousness for characteristics of the major construction, which causes the construction of traditional majors affected, gradually eliminate, a new set of majors are also hard to have a great development due to be congenitally deficient.

(3)Emphasis on the theory, lack of practice. Training curriculum system for applied talents should be an industry development oriented, but also can reflect the development trend of the industry, reflects the industry practice and application needs, open and dynamic structure of leading industry industrial development. However, there are curriculum system of many colleges and universities still cannot meet the requirement of cultivating applied talents. On the one hand, professional basic courses and specialized courses is not reasonable, teaching material construction is lagging behind. On the other hand, the curriculum system too much emphasis on the systematic and complete knowledge of the professional theory, teaching content pays too much attention to the theory of structural interpretation, lack of practice, case analysis. The evaluation of talent quality and curriculum mode is single, only pay attention to the subject test scores, not the knowledge application ability and practice ability to create systems into the evaluation system.

(4)Deviation of operating mechanism. Despite years of theoretical research and practical exploration for cultivation of applied talents, the situation is not just as one wishes. First of all, teachers still showed a tendency of theory, and application type, double-qualified teachers are far 
from being. Generally focusing on the background of academic level in the evaluation and promotion, it is difficult to introduce the motivation of knowledge application and practice guidance on policies and measures. Secondly, extensive school-enterprise cooperation mechanism is not established, lack of training base and training courses. Thirdly, occupation planning guidance lacks of communication and contact with international and domestic occupation certification system. Students rarely be able to participate in the occupation qualification training or all kinds of authority events for knowledge application development transformation. Fourthly, the academic management system lacks flexibility and individualization.

\section{C training mode}

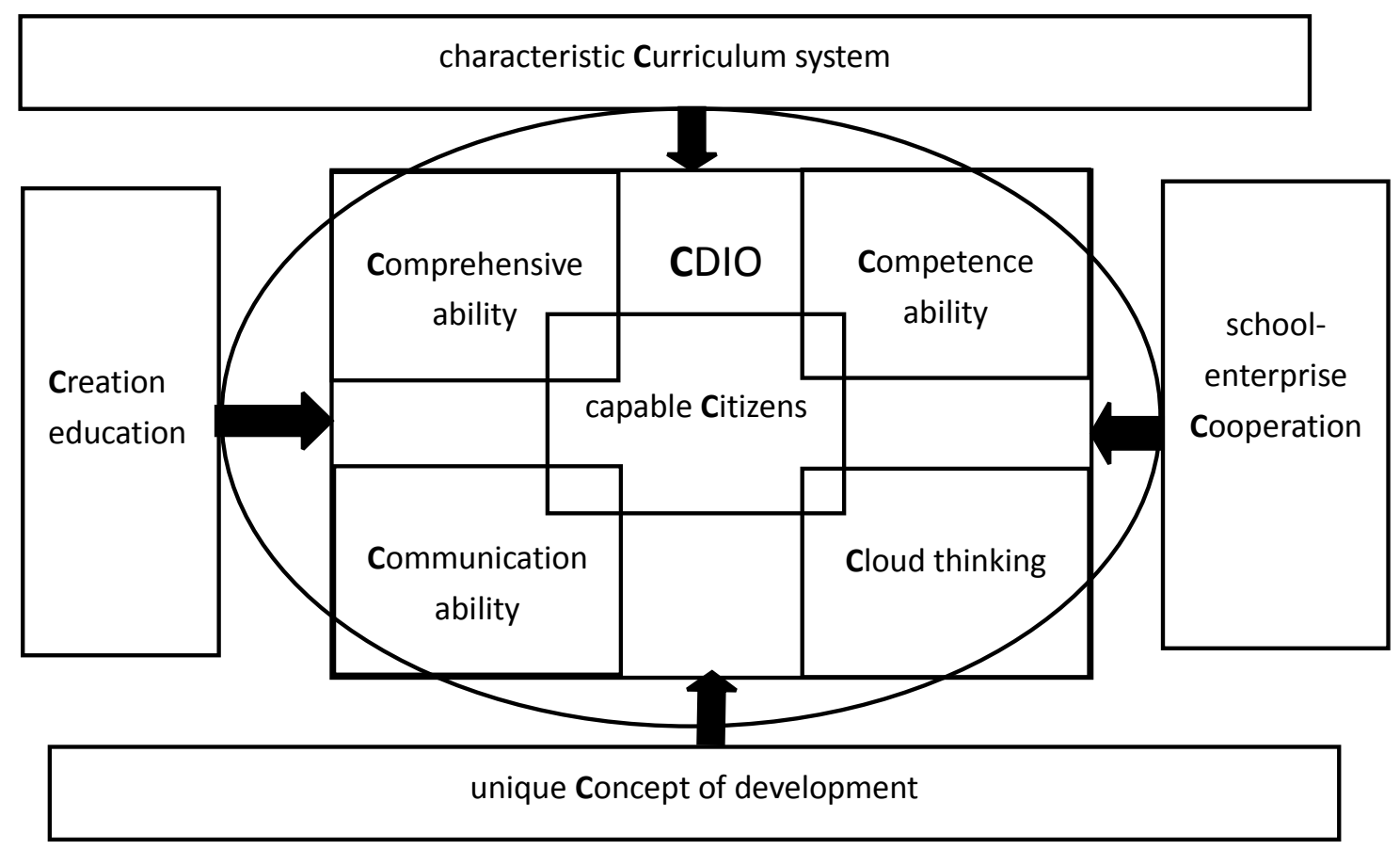

Figure. 1 10C training mode

As shown in Fig .1, we construct a 10C model for Cultivating Application-oriented Talents Based on Ability Oriented and Cooperative Education.

(1)unique Concept of development. The cultivation of talents should be practical, innovative and entrepreneurial, high employment ability.

(2)characteristic Curriculum system. The characteristic curriculum system at least has three aspects: the first is modular, students can select freely according to their needs; second is practical, which is consistent with the goal of training applied talents; third is MOOC, students can learn through the mobile internet conveniently.

(3)Creation education. The university should make creation education become a kind of culture, become the spirit of the university, into the whole process of talent training.

(4)school-enterprise Cooperation. School-enterprise cooperation is a mode of cooperation between schools and enterprises. School-enterprise cooperation focus on training quality, pay attention to students learning and practice, pay attention to the school and enterprise resources, information sharing.. The cooperation meets the society needs and in line with the market, realize combination of theory and practice. 
(5)education method based on CDIO. The CDIO education mode is the newest achievement of international engineering education reform in recent years. CDIO denotes Conceive, Design, Implement and Operate, which focuses on product life cycle from the product research to product operation, let the students learn engineer in a way of project organic connection among active, practice and course. CDIO training outlines of engineer graduates are divided into four levels: engineering basic knowledge, personal ability, interpersonal ability and team ability, ability for engineering system.

(6) Comprehensive ability. Students need to have a variety of comprehensive ability, the most important parts are self-confidence, self-reliance, hard work and dedication.

(7) Competence ability. University should train graduates to have proficiency and strong practical ability.

(8) Communication ability. The university cannot cultivate nerd and cultivate talents to be good at communication, whom achieve the goal through communication.

(9) capable Citizens. Talent cultivating should be the moral education first. University cultivate capable citizens for the society, rather than social destroyer.

(10) Cloud thinking. The Internet was originally just a technology, when people join, Internet applications and Internet era have rich humanistic color, represents a kind of spirit and thinking. This thinking is considered to include four aspects: first is open, no time limit, no geographical boundaries, but also open in the space of people's thinking; two is equality, equality and cooperation in the front of the network; three is cooperation, everyone is not only the information receiver, but also information disseminators; four is share, it is the source of the power of the development of the internet. The cultivation of students' cloud thinking is to make students have Internet thinking, able to adapt to the Internet age, can make full use of Internet tools.

\section{Acknowledgment}

This work was supported by Jiangxi Province Office of Education of Humanities and Social Science Research [No. GL 1409]. The author thanks Dr. Hu Jian-feng for help.

\section{References}

[1] Guo-ling R. Cultivation of Application Oriented Talents in Biotechnology Major Based on Cooperative Education of Production,Teaching and Research in Local College [J]. Journal of Anhui Agricultural Sciences, 2013.

[2] Hui W, College T. Cultivating application-oriented talents in the major of Business English based on cooperative Education [J]. Journal of Xinyu University, 2013.

[3] Liang T. Study on the construction of the special majors based on the cultivating mode for application-oriented talents [J]. Journal of Guizhou Education Institute, 2009.

[4] Liang T, Jian-ping J. Research on Cultivating Model for Application-oriented Talents and Its Practice [J]. Journal of Beijing Institute of Economic Management, 2008.

[5] Jian H, Hua J, College J P. Exploration of Professional Cultivation Mode of College Students Based on the Concept "People-oriented, Cooperative education" [J]. Journal of Guangdong Polytechnic Normal University, 2013. 
[6] Jihe Z, Minyang Y. Constraints Analysis on Application-oriented Training of Local Agricultural Institutions in the Perspective of Cooperative Education [J]. Guide of Science \& Education, 2011.

[7] Jinyun P. Cultivating Application- oriented Talents Based on Chemical Engineering Practice Ability in Normal Universities [J]. Guangdong Chemical Industry, 2014.

[8] Min, CAO, Jiajing, et al. The Application-oriented Mechanical Engineering Education under the Background of International Cooperation [C]. //International. 2007.

[9] Qiao-zhen T, Zheng-de H, Jin-wen G, et al. Cooperative education of teaching-research-production for cultivating innovative TCM talents [J]. Journal of Traditional Chinese Medicine University of Hunan, 2012.

[10]Qing-ju H. The Study and Practice of Enterprise-University-Research Integration Education Mode for Application-Oriented Students of Environmental Engineering Specialty [J]. Journal of Anhui Agricultural Sciences, 2012.

[11]Quan L. Construction Teaching Team in Electrics and Electronics Series Course and Cultivating Innovation and Application-oriented Talents [J]. Anhui Agricultural Science Bulletin, 2013.

[12]Runhua Q, Lingyun H. Thoughts on Cultivating Application-oriented Talents Majoring in Composite Materials and Engineering [J]. Guangdong Chemical Industry, 2012.

[13] Shu-xi L, Dong-hong S. The Reaserch on Cooperative Education of Local Application-oriented University [J]. Computer Knowledge \& Technology, 2014.

[14]Yi-hua C, Su-juan L. Practical Teaching Models for Internationalized Application-oriented Professionals [J]. Research \& Exploration in Laboratory, 2012.

[15] Yongming G. A Research of a New Training Mode of Application-oriented Software Engineering Talents [J]. Journal of Chongqing Three Gorges University, 2014. 